\title{
1. Public policy and mandatory rules of law: definition, distinction, and function
}

Prior to discussing the substantive role mandatory rules play in different stages of international arbitration it is necessary to first discuss the nature, definition, categories, and function of public policy and mandatory rules of law.

In general, public policy reflects fundamental values and principles of every State, which based on its importance and sphere of application has various categories. Under the general term "public policy," there appear to be other further narrow and highly important policies labeled as "domestic public policy," "international public policy," and even "transnational public policy." The first parts of this chapter mostly define and distinguish these concepts from one another.

The discussion then turns to "mandatory rules of law" in terms of where they stand in a legal system, how they function differently from public policy, and their interrelation and applicability.

Finally, since choice of law and party autonomy are raised in various parts of this research, the concept of mandatory rules in conflict of laws is also discussed here.

\section{PUBLIC POLICY (PUBLIC ORDER)}

Public order (or ordre public in French) bears the same meaning as the term "public policy" in Anglo-American legal terminology. ${ }^{1}$ However, it is one 
concept that is not easy to define. ${ }^{2}$ One authority described it as "a very unruly horse, [that] once you get astride it you never know where it will carry you." It is observed that public policy "reflects the fundamental economic, legal, moral, political, religious and social standards of every State - or extra-national community," or as Cardozo J. stated: "fundamental principles of justice, some prevalent conception of good morals, some deep-rooted tradition of common weal." 5

Each State or community has its own or even common "principles and standards which are so sacrosanct as to require their maintenance at all costs and without exception." ${ }^{\circ}$ Thus, it is true to say that the concept depends on the judgment of the concerned legal system and is subject to change over the course of time. ${ }^{7}$

In Egerton v. Brownlow (1853), the House of Lords described public policy as "that principle of law which holds that no subject can lawfully do that which has a tendency to be injurious to the public or against public good." Perhaps when public policy deprives an international contract of legal effect, it is true

2 See Besant v. Wood (1879), L. R. 12 C. D. 620 (Jessel, M.R.) ("It is impossible to say what the opinion of a man or a Judge might be as to what public policy is); also see Lew, Applicable Law (n 1), at 531 ("The uncertainty and ambiguity as to its actual content is one of the essential characteristics of public policy"); see also Pierre Lalive, Transnational (or Truly International) Public Policy and International Arbitration, in P. Sanders (ed.), Comparative Arbitration Practice and Public Policy in Arbitration (ICCA Congress Series No. 3, 1987) 257, 273 (the "difficulty, not to say the impossibility" of defining public policy with precision); Kekewich, J., Davies v. Davies (1887), L. R. 36 C. D. 364 ("Public policy does not admit of definition and is not easily explained. It is a variable quantity; it must vary and does vary with the habits, capacities, and opportunities of the public").

3 See Richardson v. Mellish [1824-34] All E.R. Rep. 258 (Common Pleas), at 303; also, see M.R. Smith, The Driefontein Consolidated Mines, Ltd v. Janson (1901), Times L. R., Vol. XVII, 605 ("Public policy is a high horse to mount, and is difficult to ride when you have mounted it"); Tindal, C.J., Horner v. Graves (1831), 7 Bing. 743 ("Whatever is injurious to the interests of the public is void, on the grounds of public policy"); also, see Holman v. Johnson (1775), Cowp. 343 (where Lord Mansfield stated: "the principle of public policy is this: ex dolomalo non orituractio. No Court will lend its aid to a man who founds his cause of action upon an immoral or illegal act").

$4 \quad$ Lew, Applicable Law in International Commercial Arbitration (n 1), at 532.

5 See Loucks v. Standard Oil Co. of New York, 224 N.Y. 99, 120 N.E. 198, 202 (N.Y. Jul 12, 1918); see also generally, Monrad G. Paulsen and Michael I. Sovern, "Public Policy" in the Conflict of Laws, 56 Colum. L. Rev. 961 (1956).

6 Lew, Applicable Law in International Commercial Arbitration (n 1), at 532.

7 Böckstiegel, Karl-Heinz, Public Policy and Arbitrability, in Pieter Sanders (ed.), Comparative Arbitration Practice and Public Policy in Arbitration, ICCA Congress Series, 1986 New York Volume 3 (Kluwer Law International 1987) 177, 178-179.

8 Egerton v. Brownlow (1853) 4 HLC 1; see also Hay et al., Conflict of Laws (5th ed., West 2010), at 474-476. 
to say that the main reason for such prevention is based upon the necessity of giving priority to the public good rather than to individual rights and freedoms. ${ }^{9}$ In the United States, quoted frequently, "most basic notions of morality and justice" form public policy, ${ }^{10}$ or the Federal Court of Justice of Germany (Bundesgerichtshof, BGH), which used basic rules and ideas of justice to define public policy. ${ }^{11}$

The content and examples of public policy are different in each legal system. This is due to countries' cultural diversity and the fact that public policy is also known as "the utmost symbol of culture." 12 Therefore, each country determines its own public policy exception based, in part, on its cultural values.

Public policy exception is generally referred to where public interest is in contradiction with the private interests of an individual or a group of individuals and thus, due to the priority of public good, it overrides the private interest. However, application and interpretation of the public policy exception should be limited and narrow and used as the "last ditch weapon" in order to protect individual rights and freedom from becoming frequently ignored or overridden under the rubric of public policy. ${ }^{13}$

9 See Mrazek (n 1), at 90, "preferring the good of the general public to an absolute and unfettered freedom of contract on the part of individuals."

10 See International Law Association, Interim Report on Public Policy as a Bar to Enforcement of International Arbitral Awards, Committee on International Commercial Arbitration, London Conference (2000), available at http://www.newyorkconvention .org/publications/full-text-publications (last visited 03/01/13), citing Parsons \& Whittemore Overseas Co., Inc. v. Societe Generale de l'Industrie du Papier RAKTA and Bank of America 508 F. 2d 969 (2nd Cir., 1974).

11 See Interim Report on Public Policy 2000 (ibid.), citing BGH, 12 July 1990 - III ZR 174/89, NJW 1990 at p. 3210.

12 Catherine Kessedjian, Public Order in European Law, 1(1) Erasmus Law Review 36 (2007).

13 See Michal Wojewoda, Mandatory Rules in Private International Law, 7 Maastricht J. Eur. \& Comp. L. 183 (2000), 193. Restrictive application of public policy has been claimed for arbitral awards, see Kessedjian, Public Order in European Law (n 12), at 31; and also for foreign judgments, see Peter Hay, Comments on Public Policy in Current American Conflicts Law, in D. Baetge, J. von Hein and M. von Hinden (eds), Die Richtige Ordnung: Festchrift für Jan Kropholler (2009), 89, "It is generally agreed that 'public policy' should lead only exceptionally to the non-recognition of a foreign judgment"; see the US Supreme Court decision in W.R. Grace \& Co. v. Local Union 749,461 U.S. 757 (U.S. S.Ct. 1983) (that the content of public policy cannot originate from "general considerations of supposed public interest," but from "laws and legal precedents"; see also Burrough J. in Richardson v. Mellish (1824), 2 Bing. 252 ("The argument of public policy leads you from sound law, and is never argued but when all other points fail"); see also Born and Rutledge, International Civil Litigation in United States Courts (4th ed., Kluwer Law International 2007), 719-720. For US decisions rejecting public policy defenses, see Triad Fin. Est. v. Tumpane Co., 611 F.Supp. 157 
There are basically two main criteria for considering a norm or a rule as public policy. First, the rule must include "a real and severe enough danger" to qualify as a public interest, thus not every violation of the public good will suffice as a ground to say public policy was trumped. And second, the rule must protect a fundamental interest of the State. ${ }^{14}$ In this regard, the concept has been given two aspects: "fundamental principles" (e.g. pacta sunt servanda) and "mandatory rules of law" or "lois de police" (in the terms of Art. 9 of the 2008 Rome I Regulation or Art. 7 of the 1980 Rome Convention, e.g. antitrust laws). ${ }^{15}$ Although considerations of public policy and its nature are

(N.D.N.Y. 1985), Tjart v. Smith Barney, Inc., 28 P.3d 823 (Wash. App. 2001) and Miller v. Aetna Life and Cas. Co., 906 P.2d 372 (Wash. App. 1995). For other jurisdictions see e.g. Hebei Imp. \& Exp. Corp. v. Polytek Eng'g Co., XXIVa Y.B. Com. Arb. 652 (H.K. Court of Appeal, High Court 1999), 675-677 (for refusal of enforcement under the New York Convention "the award must be so fundamentally offensive to that jurisdiction's notion of justice that, despite it being a party to the Convention, it cannot reasonably be expected to overlook the objection"); Schreter v. Gasmac Inc., 7 O.R. 3d 608 , \53 (Ontario Court of Justice 1992) (“"T] he public policy defense should be construed narrowly. It should apply only where enforcement would violate our most basic notions of morality and justice").

14 Kessedjian, Public Order in European Law (n 12), at 29, driving conclusions from Case 30/77, Regina v. Pierre Bouchereau [1977] ECR, 1999. However, the author is mainly discussing European public policy.

15 See Interim Report on Public Policy 2000 (n 10). 
hard to define, ${ }^{16}$ some definition is provided for public policy in national laws ${ }^{17}$ and international conventions. ${ }^{18}$

With respect to its role in law and arbitration, public policy comes into play when a foreign law is applicable and its application is manifestly incompatible with the public policy of the forum State. In other words, the public policy of the forum State provides a reservation from the application and enforcement of a foreign law that contradicts it. ${ }^{19}$ To clarify, to the forum court, a foreign law may be the law chosen by the parties if it is other than the law of the forum, or any other law that may potentially claim application.

After an attempt to define public policy, what ought to be considered is how the public policy of the forum State actually functions when the applicable

16 See Interim Report on Public Policy 2000 (n 10), citing Deutsche Schachtbauund Tiefbohrgesellscaftmbh v. Ras Al Khaimah National Oil Company [1987] 2 Lloyd's Rep. 246 at 254, where Sir John Donaldson of the English Court of Appeals states: "Considerations of public policy can never be exhaustively defined, but they should be approached with extreme caution. ... It has to be shown that there is some element of illegality or that the enforcement of the award would be clearly injurious to the public good or, possibly, that enforcement would be wholly offensive to the ordinary reasonable and fully informed member of the public on whose behalf the powers of the State are exercised." Thus, to my understanding, public good is subject to public policy and members of the public are subject to being protected by it; see also Lalive, Transnational (n 2), at 273 (the "difficulty, not to say the impossibility" of defining public policy with precision).

17 Arts 34(2)(b)(2) and 36(1)(b)(2) of the UNCITRAL Model Law on International Commercial Arbitration (adopted 1985, with amendments in 2006), which has been adopted in many national arbitration laws. In national legislation there are countries that refer to "public policy" and "good morals," e.g. see Art. 118(3) of the Japanese Code of Civil Procedure (1996), Art. 16(1) of the Italian Act on Private International Law (1995), section 17 of the Swiss IPRG (1987) and Art. 285 of the Code of Civil Procedure; there are also countries that refer to "the principles of international public policy," e.g. Art. 1502 of Title V of the French Code of Civil Procedure (1981), Art. 1096(f) of the Portuguese Code of Civil Procedure (1986); also reflected in the Private International Law Acts of some countries with more general phrases, to name a few, e.g., see "Einfuhrungsgesetzzum Bürgerlichen Gesetzbuche" in section 6 using "fundamental principles of German law," or section 6 of "Bundesgesetz über das Internationale Privatrecht" (1978) (IPRG) stipulating "fundamental values of the Austrian legal system"; see also Audley Sheppard, Public Policy and the Enforcement of Arbitral awards: Should There Be a Global Standard? 1 TDM 1 (2004).

18 See e.g., Art. V.2(b) of the New York Convention on the Recognition and Enforcement of Foreign Arbitral Awards (1958), Art. 1(e) of the Geneva Convention (1927), Art. 2(h) of the Panama Convention (1975), Art. 37 of the Riyadh Convention (1983); for other conventions having public policy provisions, see Mrazek (n 1), at 93-94.

19 See Mrazek (n 1), at 80; see for example Art. 17 of the Swiss PILA (1987), which states: "The application of provisions of foreign law shall be precluded if it would produce a result which is incompatible with Swiss public policy (ordre public)." 
foreign law turns out to be incompatible with the forum's public policy. Public policy operates both as a shield and a sword:

as a shield it protects against foreign judgments or rules of law that are incompatible with forum law or values by denying domestic effect to such judgments or disregarding the otherwise applicable foreign law. As a weapon, it claims application and effect to the exclusion of what might otherwise be "the applicable law". ${ }^{20}$

Therefore, based on this observation, public policy plays both a preventive and an offensive role in the non-application of an inconsistent foreign law claiming application. In other words, it first blocks the non-consistent foreign law from application and then assertively claims application due to lack of appropriate "applicable law." 11

One may claim that public policy may only play a defensive role. But at the same time, public policy sets the ground for the direct application of mandatory norms, the interplay between public policy and mandatory norms, where one rejects the application of foreign law and the other guarantees the application of the forum's overriding mandatory laws to fill the gap. To further clarify, public policy is a general picture of a system's legal order, which for its protection needs to be regulated as a mandatory norm. The norm, acting as the law, then has the capability of acting offensively and being directly applicable. ${ }^{22}$ Thus, the application of overriding mandatory norms would be based on the existence of a strong operative public policy preventing the application of foreign law.

\section{INTERNATIONAL PUBLIC POLICY}

International public policy is a narrower concept than public policy, ${ }^{23}$ and "according to a generally accepted doctrine is confined to violation of really fundamental conceptions of legal order in the country concerned." ${ }^{24}$ Like

\section{See Hay, Comments on Public Policy (n 13), at 89.}

21 Ibid.

22 See Böckstiegel, Public Policy and Arbitrability (n 7), at 183 (“... it is important to note, since this is not always seen, that mandatory rules are not necessarily identical with public policy rules. Public policy requires further additional qualifications. Every public policy rule is mandatory, but not every mandatory rule forms part of public policy").

${ }_{23}$ See Interim Report on Public Policy 2000 (n 10), "International public policy is understood to be narrower than domestic public policy: not every rule of law which belongs to the ordre public interne is necessarily part of the ordre public externe or international."

24 See Pieter Sanders, "Commentary" in 60 Years of ICC Arbitration - A Look at the Future (ICC Publishing, 1984); see also Society of Lloyd's v. Ashenden 233 F.3d 
public policy, the international public policy of each country may differ from that of another country. ${ }^{25}$

The idea of international public policy has its parallel in American law by which objections on due process grounds are treated differently in international cases than in domestic ones. ${ }^{26}$ That means if a local judgment does not conform its procedural doctrines to "the latest twist and turn" of the governing domestic procedural rules, then due process has not been upheld in that judgment. ${ }^{27}$ However, the same threshold is not expected to be followed in a foreign judgment that is before an American court for enforcement. ${ }^{28}$ This is referred to as the "'international concept of due process' to distinguish it from the complex concept that has emerged from American case law." ${ }^{29}$ Thus, as far as the foreign procedure is "compatible with the requirements of due process of law," meaning that it is "fundamentally fair" and does not offend against "basic fairness," the foreign judgment should not be objectionable under due process grounds in American courts. ${ }^{30}$

In France, as another example, international public policy as referred to in Article 1502.5 of the French New Code of Civil Procedure (1981) "can only mean the French conception of international public policy, in other words,

473 (2000), where the Court considers foreign procedural law compatible with Illinois Citations Statute as long as it is "fundamentally fair" and in accord with "basic fairness," citing Ingersoll Milling Machine Co. v. Granger, 833 F.2d 680, 687-688 (7th Cir. 1987); Hilton v. Guyot, 159 U.S. at 202-203, 16 S.Ct. 139; Wilson v. Marchington, 127 F.3d 805, 811 (9th Cir. 1997); Guinness PLC v. Ward, 955 F.2d 875, 900-901 (4th Cir. 1992); Banco Minero v. Ross, 106 Tex. 522, 172 S.W. 711, 714-715 (1915).

25 "This name suggests that it is in some way a supra-national principle; however, in practice it is no more than public policy as applied to foreign awards and its content and application remains subjective to each State." See Interim Report of the ILA's Conference on Public Policy 2000 (n 10). There is also another meaning applied to international public policy as the public policy that belongs to public international law, but that is not meant here. See Pierre Mayer, Effect of International Public Policy in International Arbitration? in Loukas A. Mistelis and Julian D.M. Lew (eds), Pervasive Problems in International Arbitration (Kluwer Law International 2006), at 61.

26 See Society of Lloyd's v. Ashenden 233 F.3d 473, 476-478 (2000).

27 Ibid.

28 Ibid.

29 Ibid. For further discussion on due process, see generally, E. Thomas Sullivan and Toni M. Massaro, The Arc of Due Process in American Constitutional Law (Oxford University Press 2013).

30 Society of Lloyd's v. Ashenden 233 F.3d 473, 476-478 (2000). See also Peter Hay, Notes on the European Union's Brussels-I "Recast" Regulation - An American Perspective, 1 EuLF (2013) at 8 ("American idea of an "international concept of due process' met its limit when a foreign-country judgment did not comport with American federal constitutional rights - the question was no longer one of basic or systemic 'fairness': the forum standard became absolute"). 
the set of values a breach of which could not be tolerated by the French legal order, even in international cases." ${ }^{31}$ The Portuguese legislation refers to the "principles of Portuguese international public policy." 32 Few countries have even considered a common and universally accepted content for their international public policy, identical to "transnational public policy," respected in all civilized nations. ${ }^{33}$

In international arbitration, the drafters of the UNCITRAL Model Law also noticed "international public policy," but concluded that the underlying idea was not generally accepted and, above all, the term lacked precision. ${ }^{34}$ However, in the ILA's Final Report of the Committee on Public Policy as a Bar to Enforcement of International Arbitral Awards, members claimed that "the concept is now sufficiently well established to be used as the test of enforceability by State courts." 35 The Final Report - considering international public policy narrower in scope than domestic public policy - characterizes international public policy as "that part of the public policy of a State which, if violated, would prevent a party from invoking a foreign law or foreign judgment or foreign award." ${ }^{36}$ In the Report, it was recommended that public policy as a bar to the enforcement of arbitral awards should be refused only in exceptional circumstances and that such exceptions should be merely against international public policy. ${ }^{37}$

With respect to the sources, public policy and international public policy share the same sources, the government or the legislature of each country, thus

31 See Articles 1498 and 1502 of Title V of the French New Code of Civil Procedure (1981); see also Fouchard, Gaillard and Goldman on International Commercial Arbitration, E. Gaillard and J. Savage (eds) (Kluwer, 1999), paras 1645-1662.

32 See Article 1096(f) of the Portuguese Code of Civil Procedure (1986).

33 See "Transnational Public Policy" discussed below; also, the Milan Court of Appeals described international public policy as a "body of universal principles shared by nations of similar civilization, aiming at the protection of fundamental human rights, often embodied in international declarations or conventions," see Decision dated 4 December 1992, reported in (1997) XXII Yearbook 725. The Court also held that the public policy referred to in Art. V.2(b) of the New York Convention of 1958 is international public policy, ibid.

34 See Third Working Group Report UN Doc. A/CN.9/253 (para. 154) and Howard M. Holtzmann and Joseph E. Neuhaus, A Guide to the UNCITRAL Model Law on International Commercial Arbitration: Legislative History and Commentary (Kluwer 1989), at 919.

35 See Final Report on Public Policy as a Bar to Enforcement of International Arbitral Awards, International Law Association, New Delhi Conference (2002), Committee on International Commercial Arbitration, available at http://www.newyorkconvention .org/publications/full-text-publications (last visited 03/01/13).

36 Ibid.

37 Ibid. 
falling within that State's jurisdiction. ${ }^{38}$ However, the line that may be drawn to distinguish the two concepts is to say that higher requirements (thresholds) must be met for domestic public policy to be violated in international cases. Applying higher requirements for international public policy violations will result in the narrower application of public policy in international cases ${ }^{39}$ For instance, the English Court, in Hilmarton v. OTV ${ }^{40}$ considered "corruption" sufficiently offensive to violate English international public policy; however, "a purchase of personal influence" (the issue in the case at hand) violates purely English domestic public policy, and is thus inapplicable in cases with an international element. ${ }^{41}$ The English court recognized the wisdom of Cardozo J.'s comments in Loucks v. Standard Oil Co. in holding that "we are not so provincial as to say that every solution of a problem is wrong because we deal with it otherwise at home." 42

\section{TRANSNATIONAL PUBLIC POLICY}

Transnational public policy, also referred to as "truly international public policy," ${ }^{, 33}$ relates to a very few fundamental and basic rules of law, broadly accepted among civilized nations. ${ }^{44}$

38 See William W. Park, The Specificity of International Arbitration: The Case for FAA Reform, 36 Vand. J. Transnat'l L. 1241 (2003), 1272; and William W. Park, Why Courts Review Arbitral Awards, in Robert Briner et al. (eds), Law of International Business and Dispute Settlement in the 21st Century (Heymann 2001), 595, 605-606.

39 Public policy rarely leads to a refusal of enforcement of an arbitral award - one reason for which may be the distinction between domestic and international public policy, see Albert Jan van den Berg, Refusals of Enforcement under the New York Convention of 1958: The Unfortunate Few, in Arbitration in the Next Decade (ICC Bulletin - 1999 Special Supplement) at 86.

40 Hilmarton v. Omnium de Traitementet de Valorisation (OTV), (1999) 14(6) Mealey's IAR A1, (1999) XXIVa Y.B. Com. Arb. 777 (QBD, 24 March 1999).

${ }^{41}$ Ibid. ("It is legitimate to conclude that there is nothing which offends English public policy if an arbitral tribunal enforces a contract which does not offend the domestic public policy under either the proper law of the contract or its curial law, even if English domestic public policy might have taken a different view"); for comments see Ewan Brown, Illegality and Public Policy Enforcement of Arbitral Awards in England: Hilmarton Limited v. Omnium de Traitement et de Valorisation S.A, 3(1) Int'1 Arb. L. R. (2001), at 31 et seq.

42 Loucks v. Standard Oil Co. of New York, 224 N.Y. 99, 120 N.E. 198, 201 (N.Y. Jul. 12, 1918).

43 See generally Lalive, Transnational (n 2).

44 See Martin Hunter and Gui Conde e Silva, Transnational Public Policy and its Application in Investment Arbitrations, 4 J.W.I. 3 (2003), at 368; see also ILA Final Report on Public Policy 2002 (n 35), "public policy which is common to many States 
Pierre Lalive states the ambiguity of this term as: "few subjects are more vague, more difficult to seize and more controversial than that of the existence, contents and function of a public policy which would be 'really' or 'truly' international, and which it is better, if only for the sake of convenience, to call 'transnational'." 45 It is described as "comprising fundamental rules of natural law, principles of universal justice, jus cogens in public international law, and the general principles of morality accepted by civilized nations." 46 After all, the concept of "transnational public policy" is not expressly referred to in any judgment. ${ }^{47}$

In order to distinguish transnational public policy from public policy and international public policy, one may say that transnational public policy is much narrower in scope than the other two concepts. However, it is part of the other two concepts and, more importantly, recognized by other States. ${ }^{48}$ In other words, every transnational and international public policy is part of domestic public policy and can be enforced in domestic cases, but not every domestic public policy should be enforced in the international context.

The French Court of Appeals noted that bribery was against French public policy as well as the ethics of international commerce as understood by many States in the international community. ${ }^{49}$ Another example is the "uphold[ing] of fundamental human rights," such as "abhorrence of slavery, racial, religious and sexual discrimination, kidnapping, murder, piracy, terrorism." ${ }^{50}$

Sources of transnational public policy are transnational (although fully recognized by local authorities). ${ }^{51}$ Such sources may be "the general principles of law mentioned in Article 38 of the Statute of the ICJ, the preamble of inter-

(which is better referred to as 'transnational public policy')"; Swiss Federal Tribunal decision in W. v. F. and V, Decision dated 30 Dec. 1994, (1995) Bull. ASA 217.

45 Lalive, Transnational (n 2), at 258.

46 See also ILA's Final Report on Public Policy 2002 (n 35), stating: "public policy which is common to many States (which is better referred to as "transnational public policy')."

47 See ILA's Interim Report on Public Policy 2000 (n 10).

48 See Lalive, Transnational (n 2), at 295-296; see also ILA's Final Report on Public Policy 2002 (n 35).

49 See European Gas Turbines SA v. Westman International Ltd, 30 Sept. 1993, (1994) reported in (1995) XX Yearbook at p. 198.

50 See Lew, Applicable Law in International Commercial Arbitration (n 1), at 535.

51 See James D. Fry, Désordre Public International under the New York Convention: Wither Truly International Public Policy, 8(1) Chinese J. Int'l L. 81 (2009), at 89 ("these public policy considerations derive from an international source that exists above the State, with enforcement States merely giving effect to these pre-existing considerations and not interpreting them or changing them to suit their own needs"). 
national conventions and certain provisions therein, Jus Cogens, international custom and authoritative international awards." 52

In the context of transnational public policy, it would also be relevant to briefly mention that norms that are accepted and recognized by the international community, from which no derogation is permitted, are called peremptory norms or jus cogens. ${ }^{53}$ Jus cogens, however, governs State behavior, being peremptory on States and thus representing a concept of public international law rather than private international law. Jus cogens has been described as rules of international law that must be applied whatever the wills of individual States may be. However, norms that unlike jus cogens are merely considered as gap-fillers in the absence of any other agreed regime, and of which variations and modifications are permissible, are called jus dispositivum. ${ }^{54} \mathrm{Jus}$ cogens has been recognized by the international community in order to protect the interests of the international community as a whole. ${ }^{55} \mathrm{~A}$ few clear examples of jus cogens are the unlawful uses of force and the crimes of genocide, slavery, and piracy. ${ }^{56}$

52 Ibid.; see also Gui J. Conde e Silva, Transnational Public Policy in International Arbitration (PhD Thesis, 2007), at 144, available at https://qmro.qmul.ac.uk/xmlui/ handle/123456789/1717 (last visited 03/19/2013) (the author has drawn a distinction between primary and secondary sources of transnational public policy, with the former being strictly binding and the latter not binding. This seems to be critical as all transnational norms are binding and overridingly mandatory).

53 See Art. 53 of the Vienna Convention on the Law of Treaties (cited in Mrazek (n 1), at 95); some have considered jus cogens as "basically synonymous" with mandatory rules though in public international law, see Mrazek (n 1), 88; see also generally Evan J. Criddle and Evan Fox-Decent, A Fiduciary Theory of Jus Cogens, 34 Yale J. Int'l L. 331 (2009).

${ }_{54}$ See Gerald Fitzmaurice, Third Report on the Law of Treaties (A/CN.4/115), (2) Yearbook of International Law Commission (New York, United Nations 1958).

55 See Mrazek (n 1), at 96.

56 Ibid. at 97; see also the concept of erga omnes, which in international law has been used as a legal term describing obligations owed by States towards the community of States as a whole. The concept was recognized in the International Court of Justice's decision in the Barcelona Traction case (Belgium v. Spain) (Second Phase) ICJ Rep. 1970, 3 at para. 33: " $\ldots$ an essential distinction should be drawn between the obligations of a State towards the international community as a whole, and those arising vis-àvis another State in the field of diplomatic protection. By their very nature, the former is the concern of all States. In view of the importance of the rights involved, all States can be held to have a legal interest in their protection; they are obligations erga omnes. [at 34] Such obligations derive, for example, in contemporary international law, from the outlawing of acts of aggression, and of genocide, as also from the principles and rules concerning the basic rights of the human person, including protection from slavery and racial discrimination. Some of the corresponding rights of protection have entered into the body of general international law ... others are conferred by international instruments of a universal or quasi-universal character." 


\section{THE NOTION OF MANDATORY RULES OF LAW: WHAT RULES ARE MANDATORY?}

After defining various levels of public policy, mandatory rules should be discussed. The impact of mandatory rules of law or mandatory norms ${ }^{57}$ is one of "the most burning issues" in international arbitration practice. ${ }^{58}$ Such norms have been understood to cover both specific statutory provisions (an established law or rule) and general principles of public policy. ${ }^{59}$ However, the understanding of mandatory rules in this volume shall be specific statutory provisions with an overriding authority, thus excluding the general thought or policy behind them. Such provisions are passed by legislation so that their mandatory nature may either be expressly stated or inferred by way of interpretation. ${ }^{60}$ They may stem from national sources enacted autonomously by States, international sources derived from international conventions or general public international law rules, or supranational sources such as the EU regulations. ${ }^{61}$ The purpose of mandatory norms is twofold: not only to protect State/public interests but also to protect private interests that the State wishes to protect. $^{62}$

Although giving a universal definition for mandatory norms seems to be a hard task, enumeration of some characteristic features should sufficiently

57 See Anne-Sophie Papeil, Conflict of Overriding Mandatory Rules in Arbitration, in Franco Ferrari and Stefan Kröll (eds), Conflict of Laws in International Arbitration (Sellier 2011), at 342, fn. 4, stating that in the United States and Great Britain the term has been used as mandatory rules, overriding mandatory rules, spatially conditioned internal rules, peremptory norms, imperative norms, binding norms, and compulsive norms; in France: loi de police; in Switzerland: loi d'application immediate; in Belgium: regle direct d'applicabilite; in Italy: norme internazionalmente imperative, norme di applicazione necessaria; in Germany: Exklusivnormen, Eingriffsnormen, zwingendesRecht; in Spain: normas materiales imperativas.

58 See Marc Blessing, Impact of the Extraterritorial Application of Mandatory Rules of Law on International Contracts, in Nedim Peter Vogt (ed.), Swiss Commercial Law Series, Vol. 9 (Helbing \& Lichtenhahn 1999), at 70.

59 See Revised Comments by Bonell on "Mandatory Rules," Art. 4.1 of the UNIDROIT, pp. 12-14, Working Group for the preparation of Principles of International Commercial Contracts (3rd), Fifth session, Rome, 24-28 May 2010, available at $\mathrm{http} / / / \mathrm{www}$.unidroit.org/english/documents/2010/study50/s-50-115-e.pdf (last visited 06/30/2016).

60 Ibid.

61 Ibid

62 See Adeline Chong, The Public Policy and Mandatory Rules of Third Countries in International Contracts, 2(1) J. Priv. Int'l L. (2006), at 31, citing Peter Nygl, Autonomy in International Contracts (Clarendon Press 1999). 
facilitate understanding of the concept. ${ }^{63}$ As mentioned earlier, characteristically, mandatory rules of law are considered as provisions with an imperative nature, thus directly applicable within their sphere of application, irrespective of the chosen law governing parties' commercial relationship. ${ }^{64}$ They are claimed as rules "that would not meet their objectives if not applied to a number of situations which they define themselves." 65

Such rules may reach a level of high importance and become so sacrosanct that some authorities consider them directly applicable, notwithstanding the applicable conflict of laws rule method. In this regard, the Swiss Federal Tribunal states:

the foreign law need not be investigated if Swiss provisions apply directly ... Those so-called lois d'application immediate (positive public policy) ... have their own field of application which replaces the general conflicts rule ... The positive public policy includes notably provisions that protect the fundamental social, political or economic interests ...66

The mandatory or imperative nature of mandatory norms does not allow contracting parties to derogate from or evade them through coming to an agreement. ${ }^{67}$ In other words, like public policy, mandatory norms are also a limitation to the principle of party autonomy, and thus applied as a tool to limit party choice and protect public interest instead, ${ }^{68}$ although they function differently from public policy. ${ }^{69}$

63 Wojewoda (n 13), at 188.

64 See Pierre Mayer, Mandatory Rules of Law in International Arbitration, 2 Arb. Int'1 274 (1986) ("Mandatory rules of law are a matter of public policy (ordre public), and moreover reflect a public policy so commanding that they must be applied even if the general body of law to which they belong is not competent by application of the relevant rule of conflict of laws").

65 See Fouchard (n 31), para. 1516.

66 See Gary B. Born, International Commercial Arbitration (Kluwer Law International 2009) at 2174, citing and quoting the Judgment of 21 January 2002, 20 ASA Bulletin 524, 527 (Swiss Federal Tribunal) (2002). The French author, Francescakis, was the first to use regles d'application immediate for mandatory norms, see Wojewoda (n 13), at 186.

${ }_{67}$ See T.C. Hartley, Mandatory Rules in International Contracts: The Common Law Approach (1997) 266 Recueil des Cours 345 (rules that cannot be "excluded, altered or limited by contract." The author considers this in a wide sense for mandatory rules.)

${ }_{68}$ See Nathalie Voser, Mandatory Rules of Law as a Limitation to the Law Applicable in International Commercial Arbitration, 7 Am. Rev. Int'l Arb. 319 (1996), 320.

69 See e.g., and compare, Arts 7(2) and 16 of the Rome Convention (1980): the former provides for application of "overriding" mandatory rules of the forum, where 
There are two criteria that are applied to consider a norm mandatory. First, parties cannot derogate from the norm by way of contract and second, the norm must reflect a high level of protection for public policy at its different levels, even domestic public policy (where then we would categorize the norm as domestically mandatory within its system of law). ${ }^{70}$ The second criterion may be based on various circumstances and factors surrounding the policy represented by the mandatory rule. For instance, as mentioned earlier, where a public policy may be enforceable in a domestic transaction it may not be intended for application in international transactions, or if otherwise, perhaps with a higher threshold for it to be violated. ${ }^{71}$ Thus, one should hesitate to list norms such as lex mercatoria or international trade usage as mandatory norms. ${ }^{72}$ This is due to the fact that parties may first exclude them from their agreements, and because they function as gap fillers in cases where they have not been excluded by the parties or have not been selected as a choice of law. ${ }^{73}$

Providing a precise list for the content of mandatory norms seems to be "potentially unpredictable and expansive." 74 However, the most frequent application of mandatory law is competition or antitrust law. ${ }^{75}$ Arms regulations, foreign Corrupt Practices Acts, exchange regulations, import and export prohibitions, and consumer protection rules also reflect statutory mandatory norms. $^{76}$

applicable, regardless of parties' choice (positive effect); while the latter allows for an exclusion of the applicable law (negative effect). Also, see Art. 9 of EC Regulation No. 593/2008 (Rome I) replacing Art. 7(2) of the Convention.

70 Mainly referring to the mandatory norm's direct applicability or claim of application: it is directly applicable if the norm is an overriding mandatory norm. It may also claim application when the rule is for example on "offer and acceptance" in English law and English law is the law chosen by the parties to govern the contract (claiming mandatory application when the norm is not foreign to the contract) or one can also cite Art. 12 of the CISG 1980, clearly making the Article mandatory when CISG is the applicable law.

${ }_{71}$ See supra at p. 17, where there is a higher threshold considered for international due process to be violated in a foreign judgment, than for due process in domestic judgments.

${ }_{72}$ See Papeil (n 57), at 364-365.

73 Ibid.

74 See Born (n 66), at 2172.

75 See Redfern and Hunter on International Arbitration, A. Redfern, M. Hunter, N. Blackaby, and C. Partasides (eds) (Oxford University Press 2009), at 204.

76 See e.g. Art. 27(2) of the English Unfair Contract Terms Act (1977); see also Voser (n 68), at 325. 


\subsection{Simple Mandatory Norms versus Overriding Mandatory Norms}

Simple mandatory rules are a category of norms that "cannot be derogated from by agreement"; $; 7$ for instance, rules on offer and acceptance in contract law are of that nature. Such rules in any legal system "do not reflect fundamental principles, but are only mandatory for reasons of legal efficiency." ${ }^{.78}$ Some have referred to them as domestic mandatory norms (considering their content as matters of internal law $)^{79}$ or simple mandatory norms..$^{80}$ They apply mandatorily only when they have been chosen to govern a contract as the applicable law (either as the parties' choice or through conflict of laws analysis), and thus have no extra-territorial application. Simple mandatory norms can be replaced by a narrower and "stronger" category of mandatory norms, called overriding mandatory norms or internationally mandatory rules, ${ }^{81}$ which should be "construed more restrictively" than simple mandatory rules. ${ }^{82}$

A clear definition was provided for overriding mandatory norms earlier at the outset of the research. ${ }^{83}$ The European Court of Justice also defined such

77 See Rome I Regulation, Arts 3(3-4), 6(2), and 8(1).

78 See Böckstiegel, Public Policy and Arbitrability (n 7), at 183.

79 See Hartley (n 67), at 348 ("Rules which cannot be excluded by a contractual provision in a domestic setting, but which are subject to the normal rules of private international law, are said to be 'domestically mandatory"').

80 Hay et al. (n 8), at 1104, citing the Rome I Regulation Preamble, Recital 37, distinguishing overriding mandatory provisions form simple mandatory rules.

81 See Rome I Regulation, Art. 9(1); see also Hartley (n 67), at 345; and an early decision in the Cassis de Dijon case (120/78, 1979 ECR 649, 662), where the European Court of Justice referred to "mandatory requirements": "Obstacles to movement within the Community resulting from disparities between the national laws relating to the marketing of the products in question must be accepted in so far as those provisions may be recognized as being necessary in order to satisfy mandatory requirements relating in particular to the effectiveness of fiscal supervision, the protection of public health, the fairness of commercial transactions and the defence of the consumer." But later in its decision in Keck (C-267/91, 1993 ECR) it used "public-interest objectives" ("... This is so even if those rules apply without distinction to all products unless their application can be justified by a public-interest objective taking precedence over the free movement of goods." See http://eur-lex.europa.eu/LexUriServ/LexUriServ.do?uri=CELEX: 61991CJ0267:EN:HTML (last visited 06/10/2013).

82 See Rome I Regulation, Preamble, Recital 37.

83 Art. 9(1) of the Rome I Regulation; see also Symeon C. Symeonides, Party Autonomy in Rome I And II from a Comparative Perspective, in K. Boele-Woelki, T. Einhorn, D. Girsberger, and S. Symeonides (eds), Convergence and Divergence in Private International Law - Liber Amicorum Kurt Siehr (2010), at 530: "A simple mandatory rule does not embody a public policy of the same high level as that which is embodied in the overriding mandatory rules of Article 9, or for that matter, the 'fundamental policy' limitation of the Restatement (Second). Moreover, the violation of a simple mandatory rule does not, without additional exceptional circumstances, justify 
norms as "national provisions compliance with which has been deemed to be so crucial for the protection of the political, social or economic order in the Member State concerned as to require compliance therewith by all persons present on the national territory of that Member State and all legal relationships within that State." ${ }^{\circ 4}$

\subsection{Mandatory Norms versus Default Rules}

Default rules are rules of law that generally apply in the absence of a choice of law by the parties and also where there is no mandatory law that would claim application in the case at hand. ${ }^{85}$ Default rules are so-called gap fillers; ${ }^{86}$ simply "a default" that fills the gap provided by the parties either purposefully or otherwise. ${ }^{87}$ Thus default rules benefit contracting parties by providing a set of non-mandatory rules to cover incomplete contract drafting. ${ }^{88}$ Since such rules function as default, parties are allowed to contract around them or even exclude them from application. ${ }^{89}$ Fine examples, considering contract law, may be rules that "specify the place of payment, the place where goods are to be delivered, the consequences of non-delivery, etc." ${ }^{90}$ One may also address

employment of the ordre public exception of Article 21. Also, although it is difficult to quantify these concepts, the overriding mandatory rules seem to pose a higher threshold than the Restatement's 'fundamental policy' limitation."

84 See Arblade (Case C-369/96) and Leloup (Case C-376/96) [1999] ECR 1-8453, at para. 30 .

85 See Hartley (n 67), at 345 ("Every legal system has rules that apply unless they are excluded by the contract ... These rules are not mandatory").

86 See Ian Ayres and Robert Gertner, Filling Gaps in Incomplete Contracts: An Economic Theory of Default Rules, 99 Yale L. J. 87 (1989), 91 (default rules have also been used as "background, backstop, fallback, gap-filling, off-the-rack, opt-in, optout, pre-formulated, preset, presumptive, standby, standard-form and supplementary rules").

87 See Christopher Drahozal, Contracting Around RUAA, Default Rules, Mandatory Rules, and Judicial Review of Arbitral Awards, 3 Pepp. Disp. Resol. L. J. 419 (2003), 420.

88 See Ayres and Gertner, Filling Gaps in Incomplete Contracts (n 86), at 91.

89 See Raymond Nimmer, Services Contracts: The Forgotten Sector of Commercial Law, 26 Loy. L. L. Rev. 725 (1993), 733 ("Default rules ... govern in the absence of contract terms to the contrary"); David Slawson, The Futile Search for Principles for Default Rules, 3 S. Cal. Interdisc. L.J. 29 (1994), at 29 ("The contract preempts a law that would otherwise have determined the rights or duties of the parties," referring to default rules).

90 See Hartley (n 67), at 345. It should be noted that default norms also have classifications among themselves. See generally Alan Schwartz, The Default Rule Paradigm and the Limits of Contract Law, S. Cal. Interdisc. L. J. 389 (1993); and Ian Ayres and Robert Gertner, Majoritarian v. Minoritarian Defaults, 51 Stan. L. Rev. 1591 (1999). 
Article 6 of the CISG, ${ }^{91}$ which states that parties can exclude the Convention from governing their sale contract or derogate from any of its provisions, if the Convention is their choice of law. However, Article 12 of the Convention (a simple mandatory norm within the Convention) may not be derogated from by the parties when the Convention is the applicable law to the contract. ${ }^{92}$

With having mandatory rules, as discussed above, whether to categorize a rule as mandatory or default depends on the interpretation of a statute enacted by the legislature. ${ }^{93}$ As far as contracts are concerned, one possible hint that may be used for such a determination is whether the rule is aiming to protect a weaker contracting party within the contract (e.g., agents in agency contracts) or a third party outside the parties' relationship (e.g. the public). ${ }^{94}$ For example, the EU Regulation on agency contracts considers a termination notice period that has to be given to the agent by the principal before terminating the agreement. This rule is mandatory and the public policy is to protect the weaker party, otherwise an early termination is void..$^{95}$

As stated earlier, another criterion is to see if the rule is aimed to protect public policy at its different levels. Otherwise, the rule is gap-filling, and thus should be treated as default. However, in cases of doubt, one should not hesitate to at least consider if a presumption exists in favor of a norm being initially default, unless and until otherwise ascertained. Undoubtedly, in the case of conflict between the two, mandatory rules override default rules due to their imperative nature, as the latter bear a supplemental legislative purpose. When the conflict is between a simple mandatory norm and an overriding one, the overriding norm prevails, thus a fortiori in the case of conflict between a default norm and a mandatory norm (regardless of it being simple or overriding), the mandatory norm overrules the default.

91 United Nations Convention on Contracts for the International Sale of Goods (Vienna, 1980) (CISG).

92 Art. 6 states: "The parties may exclude the application of this Convention or, subject to article 12, derogate from or vary the effect of any of its provisions." Art. 12 submits: "Any provision of article 11, article 29 or Part II of this Convention that allows a contract of sale or its modification or termination by agreement or any offer, acceptance or other indication of intention to be made in any form other than in writing does not apply where any party has his place of business in a Contracting State which has made a declaration under article 96 of this Convention. The parties may not derogate from or vary the effect of this article."

93 See Drahozal, Contracting Around RUAA (n 87), at 420. On the distinction between mandatory rules and default rules, see also comment d. to section 1.2. (c) of the Restatement of the US Law of International Commercial and Investor-State Arbitration (2019).

94 See generally Ayres and Gertner, Majoritarian v. Minoritarian Defaults (n 90).

95 See EC Directive 86/653, Articles 15, 17, 18, and 19. 


\subsection{Public Policy and Mandatory Norms: the Shield and the Sword}

"The emancipation of mandatory rules has reached a point where the concept should be treated as a legal institution in its own right, completely separate from ordre public." 96 To draw a line between the two, according to the notion of mandatory norms protecting State interests and State-supported private interests, it may be said that they are an expression of public policy as they address policy concerns. ${ }^{97}$ However, some believe that the aim of mandatory provisions is to protect fundamental public interests and the purpose of the public policy reservation (exception) is to protect a country's basic constitutional principles. ${ }^{98}$ But this distinction seems irrelevant as both public interests and constitutional principles address public policy at the very end. Public policy in a wide sense covers all.

As said earlier, public policy is not a rule but in fact a general picture that "reflects the fundamental economic, legal, moral, political, religious and social standards of every State - or extra-national community." claiming "public policy rules," what is being referred to are mandatory rules, rules that reflect public policy and may or may not be part of public policy. ${ }^{100}$

By way of an analogy, public policy may be considered as a standard rather than a rule and as a philosophy or foundation rather than a tool. However, mandatory rules are rules/norms or tools to guarantee protection of the philosophy (the public policy) behind them, where one would not effectively function without the other. On the one hand, a mandatory norm's existence relies on a strong operative public policy and, on the other hand, a (international) public policy requires an overriding mandatory norm to claim application where the forum's policy is ignored by application of a foreign law. Thus, "referrals to mandatory rules are made in the process of selecting (rather than rejecting) the governing law," 101 but "ordre public is a safety valve for the forum, allowing

\footnotetext{
96 See Wojewoda (n 13), at 193.

97 See Chong (n 62), at 32, citing Nygl (n 62), at 206; see also Hay, Conflict of Laws (n 8), at 1104.

98 See Mrazek (n 1), at 88.

99 See Lew, Applicable Law in International Commercial Arbitration (n 1), at 532.

100 See Böckstiegel, Public Policy and Arbitrability (n 7), at 182-183 (“... mandatory rules are not necessarily identical with public policy rules. Public policy requires further additional qualifications ... Every public policy rule is mandatory, but not every mandatory rule forms part of public policy"). Those rules that are part of public policy are the overriding or internationally mandatory rules and those that are not part of public policy are just simple mandatory norms.

101 Wojewoda (n 13) at 193, citing D. Jackson, Mandatory Rules and Rules of "Ordre Public," in P.M. North (ed.), Contract Conflicts - The EEC Convention on the
} 
the court to keep its public policy intact in the process of applying foreign law."

For example, the EC Council Directive 86/653/EEC of 18 December 1986 protects self-employed commercial agents in their contractual relationships with the principal. In the second recital to the preamble, it is stated that the Directive was adopted in the light of the fact that "the differences in national laws concerning commercial representation substantially affect the conditions of competition and the carrying on of that activity within the Community and are detrimental both to the protection available to commercial agents vis-à-vis their principals and to the security of commercial transactions"; thus mentioning a strong public policy of the Community in the Directive. However, Articles 17 and 18 of the Directive are the mandatory rules behind the policy (being "the protection available to commercial agents vis-à-vis their principals and to the security of commercial transactions"). ${ }^{103}$

The policy and the mandatory rules of this Directive played their role in the Ingmar case. ${ }^{104}$ Ingmar, established in the United Kingdom, and Eaton Leonard Technologies Inc. ("Eaton"), a company established in California, had disputes about the payment of sums claimed to be due on an account, in particular, over the termination of an agency contract. The agency activities were carried out in England while the parties' law governing the agency agreement was Californian law. Ingmar sued Eaton in the English court for compensation for damage suffered as a result of the termination of its relations with Eaton. The High Court held that the Regulations (Directive being now adopted by England) did not apply, since the law of the State of California governed the contract. Ingmar appealed against that judgment to the Court of Appeal of England and Wales (Civil Division), which decided to stay proceedings and to refer the question of whether Council Directive 86/65 3/EEC of 18 December 1986 was applicable to the case before the court to the European Court of Justice for a preliminary ruling. The European Court of Justice stated,

Law Applicable to Contractual Obligations: A Comparative Study (North-Holland, 1982), at 62.

102 Wojewoda (n 13), at 194.

103 See Article 19 of the Directive which provides: "The parties may not derogate from Articles 17 and 18 to the detriment of the commercial agent before the agency contract expires."

104 Ingmar GB Ltd v. Eaton Leonard Technologies Inc. [2000] ECR I-9305. 
"The regime established by the Directive for that purpose [protecting agents] is mandatory in nature." 105 It also stated that:

Articles 17 and 18 of Council Directive 86/65 3/EEC of 18 December 1986 on the coordination of the laws of the Member States relating to self-employed commercial agents, which guarantee certain rights to commercial agents after termination of agency contracts, must be applied where the commercial agent carried on his activity in a Member State although the principal is established in a non-member country and a clause of the contract stipulates that the contract is to be governed by the law of that country. ${ }^{106}$

As mentioned above, the interrelation between the two (public policy and mandatory rules) is considerable and the way they interact to make forum States satisfied at the end of judicial confrontation with other legal regimes is different. One operates in a negative manner and the other operates positively. ${ }^{107}$ One is defensive and the other assertive. ${ }^{108}$ One comes at the beginning when threatened and prevents foreign law from application, thus opening the platform for the other to claim application and replace parties' chosen law or the otherwise applicable law. ${ }^{109}$ In other words, public policy operates as a shield and mandatory norms play the role of a sword. ${ }^{110}$

This positive and negative function has been reflected in the EC Rome I Regulation. ${ }^{11}$ Article 21 of the Regulation shows the public policy of the

Ibid. at I-9334.
106 Ibid. at I-9336.
107 See Chong (n 62), at 32; see also Born (n 66), at 2171.
108 See generally Hay, Comments on Public Policy (n 13).
109 See Kessedjian, Public Order in European Law (n 12), at 26, "As far as method is

109 See Kessedjian, Public Order in European Law (n 12), at 26, "As far as method is moment when they intervene." However, Kessedjian believes that public policy rules "intervene after the conflict of laws analysis is conducted and a foreign law is deemed applicable" but mandatory norms apply directly irrespective of a conflict's analysis, ibid. See also Peter Hay, Contemporary Approaches to Non-Contractual Obligations in Private International Law (Conflict of Laws) and the European Community's "Rome II" Regulation, 4 EuLF (2007), at 149 ("The public policy exception rejects a result arrived at after the choice-of law analysis has been made; mandatory rules obviate conflicts analysis: they are the applicable law").

110 See generally Hay, Comments on Public Policy (n 13).

111 Regulation (EC) No. 593/2008 of the European Parliament and of the Council of 17 June 2008 on the Law Applicable to Contractual Obligations (Rome I); see also Arts 7(2) and 16 of the former Rome Convention. Art. 7(2) of the Rome Convention: "nothing in this Convention shall restrict the application of the rules of the law of the forum in a situation where they are mandatory irrespective of the law otherwise applicable to the contract," and Art. 16 of the Rome Convention: "the application of a rule of the law of any country specified by this Convention may be refused only if such application is manifestly incompatible with the public policy ('ordre public') of the forum" 
forum's preventive or negative function. ${ }^{112}$ However, in Article 9(1) of the Regulation, the assertive function of overriding mandatory norms is reflected.

It is worthy of note that some scholars have articulated the argument that public policy sometimes applies in a positive fashion. ${ }^{113}$ However, it is still the mandatory norm of another State that is functioning positively or assertively, although with the support of the forum's public policy. ${ }^{114}$

In any case, it is asserted that the outcome of applying one positively and the other negatively is the same, ${ }^{115}$ as "the labeling 'positive' or 'negative' is mostly ... a question of ... point of view." 116 And finally when the clash is between a forum's public policy and a foreign mandatory norm, it is the public policy that has "the final overriding power." 117

- the former showing the positive function of mandatory rules and the latter the negative or preventing function of public policy.

112 See Art. 16 of the Rome Convention of 1980 on Contractual Obligations, stating: "The application of a rule of the law of any country specified by this Convention may be refused only if such application is manifestly incompatible with the public policy ('ordre public') of the forum."

113 See Chong (n 62), at 33, fn. 41, citing e.g. S. Lee, Restitution, Public Policy and the Conflict of Laws, 20 U. Queensland L.J. 1 (1998), 4-6; and M. Forde, The "Ordre Public" Exception and Adjudicative Jurisdiction Conventions, 29 Int'l \& Comp. L.Q. 259 (1980), 260.

114 See Chong (n 62), at 33-35, where the author raises two English cases of Foster v. Driscoll [1929] I KB 470, and Regazzoni v. KC Sethia [1958] AC 301, where English law was the parties' choice; however the emphasis was on "international comity," being the English public policy that encouraged the English Court to give positive application to its own public policy, therefore giving indirect effect to a third country's mandatory norm to avoid contracts of illegal performance in those friendly third countries - the US and India in these cases. In Regazzoni the Court held that: "Just as public policy avoids contracts which offend against our own law, so it will avoid at least some contracts which violate the laws of a foreign State, and it will do so because public policy demands that deference to international comity," Regazzoni, at p. 510. In Foster the Court realized that recognizing the illegal contract would "furnish a just cause for complaint by the United States Government against our Government ... and would be contrary to our obligation of international comity as now understood and recognized, and therefore would offend against our notions of public morality," Foster, at p. 319.

115 See Born, International Commercial Arbitration (n 66), at 2171, fn. 18, citing J. Hill, The Law Relating to International Commercial Disputes (2nd ed., Lloyd's of London Press 1998) $\$ 15.3 .20$.

116 Ibid.

117 Wojewoda (n 13) at 194; but see also Loukas A. Mistelis, Mandatory Rules in International Arbitration: Too Much Too Early or Too Little Too Late? Concluding Remarks, 18 Am. Rev. Int'l Arb. 217 (2007), at 223: "Despite the fact that some scholars express the view that the values behind mandatory rules stricto sensu (or 'lois de police') are considered not to be the same as those behind public policy, the distinction is unnecessary in practice. Effectively the functions of international public policy and international mandatory rules ought to be the same and normally are. What is high- 


\section{MANDATORY NORMS AS REFLECTED IN CONFLICT OF LAWS: AN INTRODUCTION}

Mandatory norms are not a new phenomenon in private international law but they have remained a controversial topic in the field. The concept has been so crucial that it has found a place in the most important domestic and international legislative instruments. ${ }^{118}$ Generally, based on the traditional conflict of laws rule, after a conflict analysis it is only the governing law that will apply to the relationship in question. ${ }^{119}$ However, as mentioned earlier, mandatory norms are an exception to this rule as they may be applied directly, despite any conflict analysis determining the applicable/governing law, or indirectly as an outcome of the analysis. ${ }^{120}$

Historically, after the decision of the Dutch Supreme Court in the Alnati case (1966), ${ }^{121}$ the first serious legislative attempts were made to regulate the application of mandatory norms in Europe. ${ }^{122}$ After Alnati, a few international laws that addressed mandatory norms are Article 13(2) ${ }^{123}$ of the 1969 Benelux Treaty on uniform rules of private international law (however it never came into force), Article $16^{124}$ of the 1978 Hague Convention on the law applicable

lighted is the importance to view and consider the restrictive version of public policy, what is often labeled international or transnational public policy and to consider their mandatory rules equivalent rather than an overly domestic version of mandatory law."

118 See Wojewoda (n 13), at 183.

119 See Wojewoda (n 13), at 185.

120 See Chong (n 62), at 40-47, discussing indirect and direct modes of application of a third country's laws by the forum court.

121 See Decision of the Hoge Raad of 13 May 1966, 56 Revue Critique de Droit International Privé (1967), 522 cited by Wojewoda (n 13), at 186, where the court agreed that in some circumstances a Dutch court should respect and apply a third country's mandatory rules notwithstanding the parties' choice.

122 See Wojewoda (n 13), at 186; Chong (n 62), at 47, 48; see also Jan-Jaap Kuipers, EU Law and Private International Law: The Interrelationship in Contractual Obligations (Martinus Nijhoff Brill 2011), at 58-60.

123 See Kurt Nadelmann, Comment: The Benelux Uniform Law on Private International Law, 18 Am. J. Comp. L. 406 (1970), 411 ("Article 13 now takes as point of departure the freedom of the parties to choose the applicable law. A limitation is set: When a contract is 'clearly localized in one country,' the parties may not disregard provisions in the local law which excludes the application of any other law. In the absence of a choice of law, the law of the country with which the contract has the "closest relations' shall apply"); see also Kuipers (n 122), at 59-60.

124 Art. 16 states: "In the application of this Convention, effect may be given to the mandatory rules of any State with which the situation has a significant connection, if and in so far as, under the law of that State, those rules must be applied whatever the law specified by its choice of law rules." 
to agency and Article $16^{125}$ of the 1984 Hague Convention on the law applicable to trusts. ${ }^{126}$

Until recently, ${ }^{127}$ the Rome Convention of 1980 has been one of the finest examples of the use of mandatory rules in private international law. Regarding mandatory norms, it constituted "a system," providing a criterion for the application of forum and foreign mandatory laws. ${ }^{128}$ Article 7(2) gives special priority to the forum's mandatory norms by stating: "Nothing in this Convention shall restrict the application of the rules of the law of the forum in a situation where they are mandatory irrespective of the law otherwise applicable to the contract." Also, Article 9(6) of the Convention raises the issue of overriding mandatory norms regarding requirements of the form of immovable property. It should be noted, however, that Articles 3(3), 5(2) and 6(1) of the Convention address simple mandatory norms which apply only when the parties themselves chose the applicable law but not when it was designated by other rules. ${ }^{129}$

125 See Art. 16, which states: "The Convention does not prevent the application of those provisions of the law of the forum which must be applied even to international situations, irrespective of rules of conflict of laws. If another State has a sufficiently close connection with a case then, in exceptional circumstances, effect may also be given to rules of that State which have the same character as mentioned in the preceding paragraph"; for commentaries see David Hayton, The Hague Convention on the Law Applicable to Trusts and on Their Recognition, 36 Int'l \& Comp. L.Q. 260 (1987), 278-279.

126 However, outside Europe although influenced by the European Rome Convention, one may name the Inter-American Convention of 1995 on the Law Applicable to International Contracts (Mexico City Convention) which also had provisions on mandatory norms. See Art. 11 of the Inter-American Convention which states: "Notwithstanding the provisions of the preceding articles, the provisions of the law of the forum shall necessarily be applied when they are mandatory requirements. It shall be up to the forum to decide when it applies the mandatory provisions of the law of another State with which the contract has close ties." For commentaries, see F.K. Juenger, The Inter-American Convention on the Law Applicable to International Contracts: Some Highlights and Comparisons, 42 Am. J. Comp. L. 381 (1994), 393; see also Susie Malloy, The Inter-American Convention on the Law Applicable to International Contracts: Another Piece of the Puzzle of the Law Applicable to International Contracts, 19(2) Fordham Int'1 L. J. 662 (1995), 719-720.

127 See Art. 9 of the EC Regulation No. 593/2008, on the Law Applicable to Contractual Obligations (Rome I Regulation).

128 See Wojewoda (n 13), at 184.

129 See Wojewoda (n 13), at 197; see also Chong (n 62), at 50-53. 
Article 7(1) of the Convention opens a back door to the application of "foreign," though overriding, mandatory norms to the contract when it is neither lex causae nor lex fori, ${ }^{130}$ by stating that:

when applying under this Convention the law of a country, effect may be given to the mandatory rules of the law of another country with which the situation has a close connection, if and in so far as, under the law of the latter country, those rules must be applied whatever the law applicable to the contract. In considering whether to give effect to these mandatory rules, regard shall be had to their nature and purpose and to the consequences of their application or non-application.

The criterion applied is the fact that the foreign overriding mandatory norm must have a "close connection" to the contract, although it was said that the criterion was vague. ${ }^{131}$ Such determination is left to judges' discretion. ${ }^{132}$

Article 9 of the Rome I Regulation replaced Article 7 of the Rome Convention on the Law applicable to Contractual Obligations. Some praise the provision on mandatory norms in the Regulation (and its proposal) by comparing it to its predecessor, the 1980 Rome Convention, ${ }^{133}$ though there are still opponents raising objections over the Regulation adopted in 2008. ${ }^{134}$ According to the Regulation, overriding mandatory norms apply "to any situation falling within their scope, irrespective of the law otherwise applicable," thus referring to their direct application. Generally speaking, one may say that the definition of mandatory rules under the regulation "emphasizes not only the imperative nature of the new rules but also their content representing the public interests of the country concerned." 135

Article 9(2) considers mandatory norms of the lex fori by clarifying that "nothing in this Regulation shall restrict the application of the overriding mandatory provisions of the law of the forum." However, the more controversial

130 See Wojewoda (n 13), at 202.

131 See Chong (n 62), at 57; examples given for the "close connection" requirement could be the place of performance or the residence or place of business of one of the parties in that third country, see Chong (n 62), at 57, fn. 207, citing M. Giuliano and P. Lagarde, Report on the Convention on the Law Applicable to Contractual Obligations, (1980) OJ C282, at 27.

132 See Chapter 4; see also Andrea Bonomi, Overriding Mandatory Provisions in the Rome I Regulation on the Law Applicable to Contracts, 10 Y.B. Priv. Int'1 L. 285 (2008), 296.

133 See generally Chong (n 62).

134 See generally Andrew Dickinson, Third-Country Mandatory Rules in the Law Applicable to Contractual Obligations: So Long, Farewell, Auf Wiedersehen, Adieu? 3(1) J. Priv. Int'1 L., 53 (2007), 74-85.

135 See Monika Pauknerová, Mandatory Rules and Public Policy in International Contract Law, 11(1) ERA Forum 29 (2010), 39. 
part of the Article is part 3 regarding application of foreign overriding mandatory norms. Article 9(3) states:

Effect may be given to the overriding mandatory provisions of the law of the country where the obligations arising out of the contract have to be or have been performed, in so far as those overriding mandatory provisions render the performance of the contract unlawful. In considering whether to give effect to those provisions, regard shall be had to their nature and purpose and to the consequences of their application or non-application.

Article 9 imposes more specific restrictive conditions on the application of third country mandatory norms than the Convention, but still has the uncertainty element and upholds the discretionary evaluation factor by judges. ${ }^{136} \mathrm{It}$ also only provides consideration of mandatory norms that render the performance of the contract unlawful, but why not, for example, the place where the judgment is to be executed? ? $^{137}$

Other European pieces of legislation that raise issues of public policy and overriding mandatory provisions today are the Rome II ${ }^{138}$ and III Regulations. ${ }^{139}$

136 See Bonomi (n 132), at 296-297.

137 Ibid.; see also Michael Hellner, Third Country Overriding Mandatory Rules in the Rome I Regulation: Old Wine in New Bottles? 5 J. Priv. Int'l L. 447 (2009), 464 ("If we examine the criterion of close connection more closely, we will find that in practice the new rule and the limitation to place of performance might not bring about such great differences"). Connecting factors such as habitual residence or nationality of one of the parties are highly unusual in practice (ibid.).

138 Regulation (EC) No. 864/2007, apart from the usual mandatory public policy provisions (Arts 16 and 26 referring to priority of forum's mandatory norms and public policy respectively); there is for instance a built-in public policy combination when one law applies as a result of Art. 4(2) where it states: "However, where the person claimed to be liable and the person sustaining damage both have their habitual residence in the same country at the time when the damage occurs, the law of that country shall apply." But account must also be taken of another law under Art. 17 where it states: "In assessing the conduct of the person claimed to be liable, account shall be taken, as a matter of fact and in so far as is appropriate, of the rules of safety and conduct which were in force at the place and time of the event giving rise to the liability."

139 See Regulation (EU) No. 1259/2010, L343, 20 December 2010, at 10-16, apart from the usual public policy exception in Article 12 (referring to the forum's public policy), Recital 35 makes it clear that the public policy (interest) ground for refusal of applying foreign law should be applied in "exceptional circumstances" and "the courts should not be able to apply the public policy exception in order to disregard a provision of the law of another State when to do so would be contrary to the Charter of Fundamental Rights of the European Union, and in particular Article 21 thereof, which prohibits all forms of discrimination." For a discussion on the application of mandatory rules in courts, via conflicts law and under national legislation, see Chapter 4. 